\title{
Clinical manifestations secondary to soft contact lens wear
}

\author{
M. RUBEN, N. BROWN, D. LOBASCHER, J. CHASTON, AND J. MORRIS \\ From Moorfields Eye Hospital, London
}

Soft hydrophilic (gel) contact lenses have been in use for a decade since they were introduced by Wichterle, Lim, and Max Dreifus, but their development as a commercial enterprise has taken place only during the past five years. It is now estimated that more than half of new patients being fitted with contact lenses have hydrophilic soft lenses. Statistics were prepared to show the clinical pattern in soft contact lens wear regarding visual acuity, keratometry, state of lids, conjunctivae, cornea, atopy, and contraceptive pill implications. Some data have previously been given (Chaston and Morris, 1975 ; Brown and Lobascher, 1975; Ruben, 1975; Chaston, 1974). The data have been programmed by computer but the results will be discussed in the light of clinical experience. This report is concerned chiefly with the analysis of clinical data. Data concerning lens behaviour, visual acuity, and wearing patterns were given previously (Chaston, 1974).

\section{Population}

A total of 15 I volunteers were fitted with five types of hydrophilic soft lenses and studied for one year by ophthalmologists and ophthalmic opticians.

Patients were allowed to wear the lenses for the maximum tolerable times daily; care and disinfection of the lenses were as advised by the manufacturers.

\section{Results}

The computer results were based on a data analysis collected over one year and the significance of the results determined by $\chi^{2}$ fraction $P<0.05$. The details are shown in Tables I to VI.

Of the I I I patients 76 had had previous experience with hard lenses and five of that group wore hard lenses successfully with good daily tolerance. Forty-eight gave a clear history of allergy and 30 had allergies affecting the skin. Forty women out of 106 were taking the contraceptive pill, representing $37 \cdot 7$ per cent (Table I).

The wearing time, as averaged for the whole year, was I I hours daily to the nearest hour and for

Address for reprints: M. Ruben, FRCS, Director of Contact Lens Department, Moorfields Eye Hospital, High Holborn, London WCIV 7 AN
Table I Details of patients

\begin{tabular}{|c|c|}
\hline & No. of patients \\
\hline Complete records (initial) & I 5 I \\
\hline $\begin{array}{l}\text { Complete records (other } \\
\text { than initial) }\end{array}$ & 231 \\
\hline $\begin{array}{l}\text { Patients with } \\
\text { previous contact lens }\end{array}$ & \\
\hline wear & 50 \\
\hline allergy & 32 \\
\hline allergy of skin & 20 \\
\hline Patients on pill & $\begin{array}{l}26 \text { (as percentage of total) } \\
38 \text { (as percentage of } \\
\text { women) }\end{array}$ \\
\hline Male to female ratio & 3 to 7 \\
\hline
\end{tabular}

Table II Average wearing time

\begin{tabular}{|c|c|}
\hline & Hours \\
\hline $\begin{array}{l}\text { on pill } \\
\text { not on pill }\end{array}$ & $\begin{array}{l}\text { I I } \cdot 3 \\
\text { I I } 3\end{array}$ \\
\hline $\begin{array}{l}\text { Yearly average for Schirmer's test } \\
\text { women on pill } \\
\text { women not on pill } \\
\text { men }\end{array}$ & $\begin{array}{l}m m \\
16 \cdot 7 \\
18 \cdot 1 \\
18 \cdot 3\end{array}$ \\
\hline
\end{tabular}

Table III Corneal tear film

\begin{tabular}{ll}
\hline & $\begin{array}{l}\text { Percentage with } \\
\text { defects in film } \\
\text { continuity }\end{array}$ \\
$\begin{array}{l}\text { Initial readings } \\
\text { On pill } \\
\text { Not on pill }\end{array}$ & 19 \\
\hline $\begin{array}{l}\text { After 12 months } \\
\text { Men and women (total) }\end{array}$ & 24 \\
\hline $\begin{array}{l}\text { Corneal thickness } \\
\text { On pill } \\
\text { Not on pill }\end{array}$ & 33 \\
\hline
\end{tabular}

those patients not on the pill there was no significant difference (Table II). The yearly average for Schirmer's tears test was $16.7 \mathrm{~mm}$ for women on 
Table IV Disease

\begin{tabular}{lll}
\hline & \multicolumn{2}{l}{ Lesions (as percentage of total) } \\
\cline { 3 - 3 } Examination & $P E K$ & Blepharitis \\
\cline { 3 - 3 } & & 33 \\
Initial visit & 4 & 35 \\
Three months & 27 & 46 \\
Six months & 37 & 48 \\
One year & 43 & \\
\hline
\end{tabular}

the pill compared with I8. I $\mathrm{mm}$ for women not on the pill, and for men this was $18.3 \mathrm{~mm}$. Thus there is an indication that women on the pill may have a decrease in tear flow.

The precorneal tear film was examined by slitbeam microscope and defects were noted. For women on the pill, I9 per cent were found to have defects compared with 24 per cent of women not on the pill. Whereas for both men and women after one year the figure was 33 per cent (Table III).

Pathological changes in the eye tissues were noted under punctate epithelial keratitis (PEK) alone and with blepharitis; blepharitis and hyperaemia was also correlated over the whole period with the time the lenses had been worn (Table II). The observations were recorded at three-monthly intervals. The prevalence of PEK to the nearest single percentage was 4 per cent initially, with a rapid progression after three months of wear to 27 per cent and at one year to 43 per cent. When correlated with blepharitis it was found that of the PEK group 26 per cent had blepharitis. Blepharitis, itself, was commonly noted: 33 per cent at the initial examination but increasing to 48 per cent after one year's wear.

Hyperaemia of the conjunctivae increased during the whole period of observation (Table IV).

The precorneal tear defects for the whole group (15I) were further analysed into the periods of observation. Thus 9 per cent showed defects at the initial visit and by the end of the year 33 per cent showed defects. Tear film defects were noted when dry spot areas (Girard, 1970) were to be seen. Schirmer's tear test when grouped and averaged at the three-monthly visit showed $16.0 \mathrm{~mm}$ at initial examination and $19.3 \mathrm{~mm}$ at the 12 -monthly visit (Table V).

The average corneal thickness (pachymetry) readings in the axis of fixation using a HaagStreit pachometer showed an initial average reading of 0.54 and after 12 months this was 0.57 . When correlated with the wearing pattern it was found that there was not sufficient evidence to suggest any increase in total corneal thickness with increased wearing time. The 20-24-hour wearers were only a group under five in number and the lower readings were not of significance. The gradual overall increase of corneal thickness, however, is of significance (Table VI).

There were other findings that are not easy to present statistically. Thus, while corneal sensation was measured with a Cochet Bonnet anaesthiometer it must be recognized that this is a test that has an inconsistent result. Investigators reported subnormal readings in only 4 per cent (nearest I per cent) at the end of the one-year period.

The lens movement on the eye was recorded at each visit but showed no relationship with changes in corneal thickness.

Corneal microcysts are evidence of chronic changes in the superficial cells of the epithelium and initially these were noted in 4 per cent of patients; however, more than 30 per cent had them by the end of the first three-month period of contact lens wear and a final figure of 26 per cent had them at the 12-month examination. Other evidence of disease was epithelial and sub-epithelial

Table V Precorneal tear film defects (as percentage of whole)

\begin{tabular}{|c|c|}
\hline Examination & Percentage \\
\hline Initial visit & 9 \\
\hline Three months & 35 \\
\hline Six months & 30 \\
\hline One year & 33 \\
\hline Skin allergy $v$. tear film defects & \\
\hline $\begin{array}{l}\chi^{2} \\
\text { Other allergy } y \text { tear film defects }\end{array}$ & $=5.7662 \mathrm{P}<0.05$ \\
\hline$\chi^{2}$ & $=3 \cdot 6 / 6_{5}$ \\
\hline Schirmer's test (average) & $m m$ \\
\hline Initial visit & $16 \cdot 0$ \\
\hline Three months & $18 \cdot 1$ \\
\hline Six months & $18 \cdot 9$ \\
\hline $\begin{array}{l}\text { One year } \\
\text { Significant at } 5 \text { per cent level }\end{array}$ & $19 \cdot 3$ \\
\hline
\end{tabular}

Table VI Corneal thickness (average of all readings)

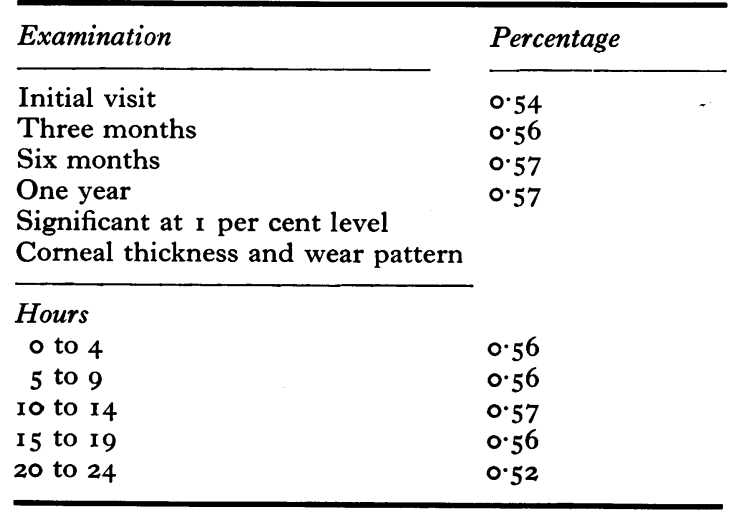


punctate keratitis in nine patients; filamentary type keratitis in six, epithelial hypertrophy at upper limbal area in one patient, and stromal oedema with folds in Descemet's membrane in six. Many of these patients had associated lens spoliation and all lesions resolved upon ceasing to wear the lenses. There was no overt case of infective conjunctivitis and all patients used a heat saline method of disinfection. Two patients had recurrent episodes of corneal erosion with soft lens wear that had originated with hard corneal lens lesions.

\section{Discussion}

The reason for the significant number of corneal lesions seen at the initial visit (Tables IV and V) in normal adults was that half had had previous hard corneal lens wear experience and at least five patients were still successful wearers.

While a third gave a history of some form of atopy, it was only the skin allergies that showed a positive relationship with eye lesions resulting from soft contact lens wear. The practitioner must therefore be wary of advising long wearing periods in this type of patient.

The contraceptive pill has been blamed for poor contact lens wear but, while this group did show a deficiency of tears, it did not result in lower average wearing times (Table II). Farrell (1973) had also noted this tear deficiency.

This group of patients ( $15 \mathrm{I}$ ) showed no incidence of bacterial infection with soft lens wear and, while no comparison is possible with a reported incidence of infection being higher in soft lens as compared with hard lens patients (Ruben, 1976) it must be noted that this group was carefully monitored throughout the trial and heat-saline was the chief method for disinfection.
There was an obvious rapid increase in superficial eye lesions even after a few months' wear of soft lenses and this was associated with a slight increase in corneal thickness which did not return to normal even after one year's adaptation. Thus no compensation has occurred.

The incidence of deep corneal lesions, while small in number, is of concern since endothelial decompensation in patients having a latent insufficiency could occur.

Recurrent corneal erosion might be considered a contraindication for wear of soft lenses. But these patients were fitted with conventional soft lenses and not the therapeutic type.

\section{Summary}

The study of $15 \mathrm{I}$ patients wearing soft hydrophilic lenses for one year revealed no gross irreversible lesions with loss of vision. But of significance was the presence of superficial lesions of the corneal epithelium, and chronic stromal oedema. While no significant loss of wearing time was noted for women taking the pill, the decrease in tear secretion in those patients with a latent dry eye problem could just alter the balance to produce intolerance. From this report it is the long-term changes to the tissues that remain to be fully investigated for soft hydrophilic lenses.

We wish to acknowledge the financial help of the following: Smith and Nephew, and Dollond and Aitchison Ophthalmic Research Fund. Furthermore, we wish to thank the following manufacturers for their co-operation: Bausch and Lomb, Contact Lenses (Mfg) Ltd, G. T. Optics, Hydron-Lens Ltd, G. Nissel and Co Ltd, and Omega Contact Lens Ltd; also the Computer Department at the Institute of Ophthalmology for providing the data from our figures.

\section{References}

BROWN, N., and LOBASCHER, D. (1975) Proc. roy. Soc. Med., 68, 52

Chaston, J. (1974) MPh thesis (City University)

- , and MORRIS, J. (1975) Proc. roy Soc. Med., 68, 53

FARRELL, H. (1973) PhD thesis (University of Aston)

GIRARD, L. (1970) 'Corneal Contact Lens', 2nd ed., pp. I09-1 ro. Mosby, St Louis

RUBEN, M. (1975) Proc. roy. Soc. Med., 68, 5 I

(1976) Lancet, 1,138 